doi:10.4149/neo_2013_031

\title{
New insights into the role of NF1 in cancer
}

\author{
Minireview
}

L. SABOVA*, M. KRETOVA, K. LUCIAKOVA

Laboratory of mutagenesis and carcinogenesis, Cancer Research Institute, Slovak Academy of Sciences, Vlárska 7, 833 91, Bratislava, Slovakia

${ }^{*}$ Correspondence: exonsabo@savba.sk

Received September 11, 2012 / Accepted November 27, 2012

\begin{abstract}
NF1 proteins are a family of transcription factors that act either as repressors or as activators. Functional studies indicate that NF1 participate in signaling pathways that regulate cell viability, proliferation and differentiation. Participation in regulation of genes important for tumor progression and metastasizing suggests a potential value of NF1 as a prognostic factor for certain types of cancer.
\end{abstract}

Key words: NF1 (nuclear factor 1), signaling pathways, cancer development and progression

NF1 (nuclear factor one) is a transcription factor involved in the regulation of expression of many eukaryotic genes. This protein has been described first in 1982 by Nagata et al. during their studies of adenovirus replication [1]. They have isolated a $47 \mathrm{kD}$ protein from HeLa nuclei which stimulated the replication of adenovirus in vitro. It was shown, one year later, that this protein binds to the origin of adenovirus replication [2]. The exact sequences needed for efficient replication of adenovirus were identified by Guggenheimer in 1984 [3]. He identified and characterized two domains essential for replication; a $10 \mathrm{bp}$ region needed for binding of viral priming protein and the other domain, 32bp long, was essential for NF1 binding.

As NF1 was isolated from HeLa cells, it was suggested that it may play a role in the regulation of gene expression in mammalian cells. The first NF1 binding site in mammalian genome was identified in 1985 in the IgM gene [4]. The authors proposed that NF1 may represent a component necessary either for replication or for chromatin activation of the IgM gene.

\section{Discovery of cellular NF1 target genes}

Identification of NF1 binding sites in the human genomic DNA [5] and comparison with binding sites in adenoviral genome, as well as the following DNA binding tests, dem- onstrated that NF1 protein binds as a dimer to a sequence TTGGC(N5)GCCAA [6]. Quantitative analysis of binding revealed that NF1 binds tightly to the dyad symmetric sites but can also bind, though with reduced affinity, to half sites TTGGC or GCCAA [7]. Gradually, cDNAs for NF1 from human [8] rat [9] mouse [10] hamster [11] and porcine [12] tissues were isolated. The presence of multiple NF1 genes in vertebrate genomes and the ability to form many splicing variants led to confusion in nomenclature. Finally, Rupp in 1990 identified four NF1 genes in the chicken and suggested a NF1 nomenclature in higher eukaryotes: NF1-A, NF1-B, NF1-C and NF1-X, which is used today [13]. A single NF1 gene was identified in cephalochordate Branchiostoma lanceolatum, in nematode Caenorhabditis elegans and in fly Drosophila melanogaster [14]. In prokaryotes, as well as in simple eukaryotes, no NF1 homolog was found.

\section{The structure of NF1 protein}

The number of exons in NF1 genes varies with species. The DNA binding domains of NF1 are primarily encoded by exon 2. This domain is also responsible for dimerization and, moreover, is sufficient for stimulation of adenovirus replication. C-terminal domain is the transcriptional activation/repression domain. Alternative mRNA splicing in all NF1 genes generates 
multiple isoforms of C-terminal transactivation/repression domains $[15,16,17]$. It was found that NF1, similar to the majority of transcription factors, is not able to bind to compact chromatin. It binds to DNA only after chromatin mobilization mediated by histone acetylation [18].

For a long time it seemed that NF1 binding domain had no sequence homology to DNA binding domains of other transcription factors. However, sensitive Position-Specific Iterated (PSI)-BLAST database search revealed significant similarities between the Smad and NF1 transcription factors [19]. The comparison of binding domains shows that four cystein residues are present in all NF1 isoforms. Three are needed for DNA binding activity and the fourth cysteine is responsible for the oxidative inactivation of NF1 [20].

\section{Expression of NF1 proteins and their essentiality}

All four genes are predominantly expressed in the lung, liver and heart of adult mouse. Very low or undetectable levels were measured in the spleen and testes. During embryonic development the first isoform that appeared was NF1-A. NF1-A was detected 9 days postcoitum in heart and in developing brain [21].

To study the essentiality of NF1 genes, germline knockout studies were performed. Nf1 a ${ }^{-1-}$ mice have mainly neuro-anatomical defects (changes in brain development, hydrocephalus). More than $95 \%$ homozygote mice die within two weeks after birth. Surviving animals are sterile but have an approximately normal life span [22]. $\mathrm{Nflb}^{-/}$mice have also neuro-anatomical defects and die soon after birth due to defects in lung development [23]. $\mathrm{Nf}^{-1 /} \mathrm{c}^{- \text {develop normally }}$ except unique pathological defects in teeth development [24]. They have no brain defects. NF $1 \mathrm{x}^{-/-}$mice gain poorly weight what indicates an important role of NF1-X in gut and intestine development. The defects in eye and ear opening in these animals indicate an important role of NF1-X also in the development of epithelia of other organs. They have also defects in brain development [25].

\section{Participation of NF1 proteins in various cell functions}

The presence of four ubiquitously expressed distinct NF1 isogenes and the possibility to form a wide range of splicing variants, together with the ability to associate with different partners, allow the NF1 to exert diverse biological effects. Detailed studies of regulation of transcription have shown that NF1 can function either as an activator or as a repressor [26]. Thus, NF1 affects a broad range of biological activities: a) cell differentiation in embryogenesis [27]; b) regulation of proteins involved in cell-cell (28) and cell-extracellular matrix interactions important in epithelial-mesenchymal transition (EMT) [28]; c) participation in the regulation of environmental stress genes CYP1A1 [29], CYP1A2 [30], CYP2A3 [31]; d) regulation of expression of mitochondrial adenine nucleotide translocator-2 gene (ANT2), indicating the possibility that NF1 might be involved in the regulation of cell energy metabolism [32]; e) cell cycle regulation and growth arrest due to transcription regulation of genes encoding cyclin D [33], GAAD153 [34], p53 [35] and $p 21$ [36].

Recently, a very interesting feature of NF1 was discovered. Consensus NF1 binding sequences function in the genome as insulators [37]. This function could be used in gene transfer-based therapeutic approaches. These insulators limit the activation of nearby cellular genes by the enhancers present in viral vectors and can function as barrier elements that would stop the spreading of silent chromatin to ensure transgene expression.

\section{Post-translational modifications of NF1}

Post-translational modifications (phosphorylation, O-or $\mathrm{N}$-glycosylation) of NF1 can significantly influence their activities. It had been shown that insulin represses the glucose transporter GLUT4 through NF1. However, only phosphorylated NF1 acts as a repressor of GLUT4 [38]. Interestingly, it was found that biological properties of gliomas are influenced by the phosphorylation status of NF1. The genes coding the glial fibrillary acid protein (GFAP) and the brain fatty acid binding protein (B-FABP), which are the markers of glial differentiation, are regulated by NF1. The ability of NF1 to activate expression of these genes is dependent on its phosphorylation status $[39,40]$, but there is little information available on the kinases or phosphatases that catalyze its phosphorylation/dephosphorylation. However, a genome-wide screening to identify substrates of ATM/ATR kinases did reveal NF1-A as a potential substrate [41].

O-linked glycosylation has been reported to stimulate the binding of NF1-B to DNA resulting in activation of the whey acidic protein transcription [42]. Similarly, N-glycosylation of NF1-C has been postulated to improve the potential to recruit co-activator/co-repressor to cluster in promotor during early involution in the mouse mammary gland [43]. Recently, during the study of regulatory influence of an irradiated 3T3 cells feeder layer on proliferation of human keratinocytes, it was found that glycosylation of NF1 and Sp1 delayed the induction of terminal differentiation of keratinocytes. The reason for this is the prevention of proteasome degradation of glycosylated proteins. The resulting increase of Sp1 and NF1 levels plays a positive role in keratinocytes proliferation inhibiting differentiation [44].

A SUMO consensus motif in the NF1 gene was identified through a SWISSPROT database search, and SUMOylation of the NF1 has been detected both in vitro and in vivo [45]. So far, no physiological role for the SUMO-modified NF1 had been identified.

\section{NF1 protein in signaling pathways}

The importance of NF1 in regulatory functions was first suggested when it was discovered that these proteins might 
participate in the TGF- $\beta$ signaling pathway [46]. TGF- $\beta$ signaling controls a diverse set of cellular processes including cell proliferation, differentiation, apoptosis and cellular homeostasis. TGF- $\beta$ mediated signaling is propagated by two main pathways: a) through phosphorylation of Smad proteins [47]; and, b) through the activation of MAPK pathways which, in turn, may or may not include the Smad proteins [48].

Involvement of NF1 in the TGF- $\beta$ signaling pathway was first demonstrated in the study of transcriptional activation of type I collagen promotor. It was shown that TGF- $\beta$ stimulated the activity of the mouse $\alpha 2$ (I) collagen promotor [46]. A detailed analysis identified a region needed for stimulation as the NF1 binding site. TGF- $\beta$ represses the expression human adenine nucleotide translocator-2 (ANT2) and this repression is NF1-dependent $[49,50]$. Another set of data identify the growing importance of NF1 in TGF- $\beta$ signaling during skin wound healing and hair follicule cycling [51,52]. During in vitro odontoblast differentiation, NF1-C expression level is inversely proportional to the level of TGF- $\beta$ signaling molecules. Increase in TGF- $\beta$ decreases the level of NF1-C due to its degradation. The degradation is dependent on interaction between NF1-C and phosphorylated Smad2/3 complex [53].

NF1 also plays a role in MAPK signaling. NF1-dependent repression of ANT2 in growth-arrested human diploid fibroblasts is mediated by p38 [50], NF1-C2 is activated by prolactin signaling via the Janus kinase (Jak2) [54], and stress-induced transcription of insulin receptor substrate 2 (IRS2) depends on NF1 binding and activation of ERK pathway [55].

\section{NF1 in cancer development and progression}

Identification of NF1-specific binding elements in the human $\mathrm{p} 53$ promotor provided the first indication that NF1 might be involved in the development and/or progression of cancer. p53 is a well characterized tumor suppressor, mutations and/or disruptions of which are often associated with human cancer. Mutation of the NF1 site reduced the activity of the p53 promotor by $64 \%$ [35]. In addition, direct physical interactions between NF1 and p53 and p73 have been reported. p53 activity is increased when bound to NF1, whereas p 73 activity is decreased [56]. However, studies on the NF1 binding to the p53 promotor in breast cancer suggest that, though NF1 plays a role in breast cancer formation, it is not through p53. The data show differential binding of NF1 to the $\mathrm{p} 53$ promotor and a depletion or low levels of NF1 in the majority of breast cancer samples with no effect on the level of p53 mRNA [57].

Another data indicating the involvement of NF1 in cell growth processes was the finding that over-expression of NF1-X prevented the TGF- $\beta$ mediated growth arrest of mink lung epithelial cells [58]. The data showing that over-expression of NF1 can influence cell proliferation indicate its role in DNA replication and thus in cancer development. Another article supporting the role of NF1 in tumor formation was published in 2004 by Johansson [59]. These authors injected a recombinant mouse Moloney virus encoding PDGF into the brain of mice to induce gliomas. Due to the synergistic action between PDGF and genes that were inactivated by insertional mutations, several genes involved in gliomagenesis could be identified. Among the identified genes were NF1-X, NF1-A, NF1-B and NF1-C. Later, published data confirmed the participation of NF1, especially the NF1-A, in gliomagenesis but with conflicting results $[60,61]$. Therefore, it is not clear yet, if higher expression of NF1 is a good or bad prognostic factor in gliomas. In the following years, several articles appeared that showed the association of NF1 with the development and, especially, with the progression of tumors. Most data have been published on the role of NF1 in breast cancer. The first information that initiated further studies on breast cancer was obtained in Nilsson's laboratory [54]. As prolactin is the hormone regulating the mammary gland development, it is a candidate for the control of initiation and progression of breast cancer. Studies from the Nilsson group show that NF1C-2 is the main transcription factor involved in prolactin signaling, and that NF1-C2 levels in the nucleus are regulated by prolactin via a Janus kinase (Jak2) targeted for proteolytic degradation in the nucleus. Subsequent clinical studies showed that patients with primary breast tumors expressed lower levels of NF1C-2 than healthy donors [28]. However, patients expressing NF1-C2 had better prognosis compared to those without a detectable NF1-C2 in the nucleus. Moreover, virtually no NF1-C2 was detected in metastatic lymph nodes suggesting that NF1-C2 is lost during tumor progression, raising the question whether this loss facilitates metastasis. A regulatory role for NF1-C2 in metastasis is strengthened by the findings that NF1-C2 strongly represses the expression of the FoxF1 gene which induces epithelialmesenchymal transition (EMT) and invasiveness. FoxF1, when expressed at relatively high levels, suppresses the expression of E-cadherine, components of tight junctions (occludin and claudin-1) and desmosomes (desmocollin, desmoplakin and desmoglein). The expression of these proteins can prevent metastases of some types of tumors [62,63]. Thus, NF1-C2 and FoxF1 appear to be two novel potential prognostic factors in breast cancer invasion.

However, this is probably valid only for breast cancers in which prolactin plays an important role. In contrast to NF1-C2, the NF1-B isoform was shown to be an unfavorable factor in other subtypes of breast cancer. Triple negative breast cancer (TNBC), which is defined by the lack of expression of estrogen, progesterone and HER-2 receptors, exhibits recurrent amplification of regions on chromosome 9p24.1 [64]. This is the region in which the NF1-B gene is located. Furthermore, the copy number of the NF1-B gene is amplified and its expression is increased in TNBC. Recently, the relationship between the NF1-B mRNA and protein expression levels and various molecular subtypes of breast cancer was demonstrated showing an association between the NF1-B expression and nuclear grading of tumors [65]. A significantly higher level of NF1-B mRNA has been detected in the estrogen receptor (ER) negative cancer tissues and cancer cell lines as 
compared to the ER positive samples. Moreover, a significant reduction in cell proliferation rate and an increase in apoptotic signalization followed the knock-down of NF1-B expression with specific siRNA in the ER negative cell lines. A change in cell cycle distribution with an increased arrest of cells in the G2/M phase was detected by flow cytometry of the siRNA-transfected cells. These results indicate that elevated expression of NF1-B is an unfavorable prognostic factor for the ER negative breast cancers.

NF1 protein is also a negative prognostic factor for human uveal melanoma. Data obtained with cell lines derived from four individual donors diagnosed with uveal melanoma show that increased expression of NF1 leads to a more invasive phenotype of uveal melanoma [66]. Aggressiveness of melanomas (as well as of many types of cancers) is related to their ability to interact with the components of the extracellular matrix [67], such as membrane bound receptors and integrins (especially the $a 5 \beta 1 \mathrm{form}$ and its ligand fibronectin). The expression of a5 integrin is regulated by NF1 in cooperation with Sp1 and AP1. High expression of NF1 represses the $\alpha 5$ expression and, thus, leads to a more tumorigenic phenotype [66].

Considering the fact that NF1-A is the critical regulator of brain development and that glial cells show dynamic patterns of NF1 gene expression during development (see above), a change in the expression of NF1-A was investigated in gliomas. Gene expression analysis performed by Scrideli (60) compared normal and neoplastic tissues to identify genes associated with gliomagenesis. Genes that were differentially expressed in primary glioblastomas were identified. Twenty overexpressed genes were selected and their expression was validated by real time PCR. NF1-A was one of 18 genes found to be more highly expressed in glioblastomas than in control non-neoplastic tissue [60]. However, when NF1-A expression was investigated in low and high grade pediatric malignant astrocytomas and the expression was correlated with the progression-free survival, NF1-A proved to be a favorable prognostic factor [61]. NF1-A was differentially expressed in astrocytomas: it was highly expressed in the low-grade astrocytomas (WHO classification grades I and II) compared with the high-grade astrocytomas (WHO grades III and IV). Moreover, there was a significant association between the level of NF1-A expression and progression-free survival in patients with high-grade astrocytomas (WHO III and IV), higher levels of NF1-A had a beneficial effect on progression-free survival.

Further data on the role of NF1 in tumorigenesis were obtained in studies in which the genetic alterations that occurred during tumor progression were investigated. Genetic manipulation was used to prepare a mouse model for metastatic prostate cancer [68]. The model uses mutations in p53 and $\mathrm{Rb}$, as these proteins are the best characterized tumor suppressors. Mutation of the p53 most probably occurs early in carcinogenesis as approximately 50 (or more) \% of cancers has mutations in $\mathrm{p} 53$. The main function of $\mathrm{Rb}$ is the control of cell cycle progression and its inactivation facilitates uncontrolled growth. p53 and $\mathrm{Rb}$ genes in prostate cells of model animals were deleted and primary tumors, which then appeared in prostate epithelium, were subjected to further analysis. Comparative genomic hybridization assay was performed to determine if specific genetic aberration were associated with p53 and Rb deficient prostate cancer. Indeed, a set of genetic alterations associated with prostate cancer was found. The amplifications at the loci $4 \mathrm{qC} 3$ and $4 \mathrm{qD} 2.2$ have been consistently detected. These loci contain cancer-related genes NF1-B and L-myc. The results raised an intriguing possibility that the progression of prostate neoplasm associated with an inactivation of $\mathrm{p} 53$ and $\mathrm{Rb}$ may, to some extent, depend also on activation of NF1-B and L-myc.

A similar approach was used to study DNA alterations in small cell lung carcinoma (SCLC) [69]. Again, experiments were based on known data, including loss-of-function mutations in p53 and $\mathrm{Rb}$ which are observed in $75 \%$ and $90 \%$ of SCLC cases, respectively [70]. A mouse model that involved the inactivation of p53 and Rb using conditional ("floxed") alleles in these genes was used. After infection of lung with adenovirus carrying the Cre recombinase, mice developed lung carcinoma that histopathologically resembled human SCLC. To determine the genetic alterations that occurred in mice primary tumors and metastases, genome amplifications and/or deletions were evaluated. Mostly, amplification of a part of chromosome 4 was detected. Within this amplified region, NF1-B was the only gene amplified in each tumor sample. To support the role of NF1-B in this type of tumor, cell lines derived from human SCLC were investigated. It was found that, from 46 investigated human SCLC cell lines, 16 had NF1-B copy number gains. Interestingly, 11 of the cell line with NF1-B amplification also had L-myc amplification. Additionally, NF1-B amplification detected by FISH, was present in 15\% of primary human tumors samples [69].

\section{Conclusion}

In recent years, accumulated data suggest that expression of NF1 plays an important role in the regulation of cell growth and in tumorigenesis. However, changes in NF1 expression are not the primary cause of tumor formation. For example, overexpression of NF1 in chicken embryo fibroblasts showed that, though NF1 induced morphological changes and rendered the cells resistant to transformation by some nuclear oncogenes, its overexpression did not induce oncogenic transformation of cells. Thus, NF1 can not be considered as a true oncogene [71]. However, NF1 affects the expression of numerous genes important for tumor progression and metastasis. Therefore, it had been suggested that the determination of NF1 expression may be a good prognostic factor for certain types of cancer.

Taken together, there is an increasing body of data implicating NF1 in the regulation of cell growth. NF1 proteins, per $s e$, are not involved directly in the regulation of cell cycle or differentiation but they often affect the expression of genes which are important for these processes. 
Acknowledgments: We thank Dr. B.D. Nelson (University of Stockholm, Sweden) for critical reading of the manuscript. Work performed in our laboratory was supported by grants from Slovak grant agency (VEGA) to K.L (2/0074/08 and 2/0107/11).

\section{References}

[1] NAGATA K, GUGGENHEIMER RA, ENOMOTO T, LICHY JH, HURWITZ J. Adenovirus DNA replication in vitro: identification of a host factor that stimulates synthesis of the preterminal protein-dCMP complex. Proc Natl Acad Sci U S A 1982; 79: 6438-42. http://dx.doi.org/10.1073/ pnas.79.21.6438

[2] NAGATA K, GUGGENHEIMER RA, HURWITZ J. Specific binding of a cellular DNA replication protein to the origin of replication of adenovirus DNA. Proc Natl Acad Sci U S A 1983; 80: 6177-81. http://dx.doi.org/10.1073/pnas.80.20.6177

[3] GUGGENHEIMER RA, STILLMAN BW, NAGATA K, TAMANOI F, HURWITZ J. DNA sequences required for the in vitro replication of adenovirus DNA. Proc Natl Acad Sci U S A 1984; 81: 3069-73.

[4] HENNIGHAUSEN L, SIEBENLIST U, DANNER D, LEDER P, RAWLINS D et al. High-affinity binding site for a specific nuclear protein in the human IgM gene. Nature 1985; 314: 289-92. http://dx.doi.org/10.1038/314289a0

[5] GRONOSTAJSKI RM, ADHYA S, NAGATA K, GUGGENHEIMER RA, HURWITZ J. Site-specific DNA binding of nuclear factor I: analyses of cellular binding sites. Mol Cell Biol 1985; 5: 964-71.

[6] GRONOSTAJSKI RM. Analysis of nuclear factor I binding to DNA using degenerate oligonucleotides. Nucleic Acids Res 1986; 14: 9117-32. http://dx.doi.org/10.1093/nar/ $\underline{14.22 .9117}$

[7] MEISTERERNST M, ROGGE L, FOECKLER R, KARAGHIOSOFF M, WINNACKER EL. Structural and functional organization of a porcine gene coding for nuclear factor I. Biochemistry 1989; 28: 8191-200. http://dx.doi.org/10.1021/ bi00446a034

[8] SANTORO C, MERMOD N, ANDREWS PC, TJIAN R. A family of human CCAAT-box-binding proteins active in transcription and DNA replication: cloning and expression of multiple cDNAs. Nature 1988; 334: 218-24. http://dx.doi. org/10.1038/334218a0

[9] PAONESSA G, GOUNARI F, FRANK R, CORTESE R. Purification of a NF1-like DNA-binding protein from rat liver and cloning of the corresponding cDNA. EMBO J 1988; 7: 3115-23.

[10] INOUE T, TAMURA T, FURUICHI T, MIKOSHIBA K. Isolation of complementary DNAs encoding a cerebellum-enriched nuclear factor I family that activates transcription from the mouse myelin basic protein promoter. J Biol Chem 1990; 265: 19065-70.

[11] GIL G, OSBORNE TF, GOLDSTEIN JL, BROWN MS. Purification of a protein doublet that binds to six TGG-containing sequences in the promoter for hamster 3-hydroxy-3-methylglutaryl-coenzyme A reductase. J Biol Chem 1988; 263: 19009-19.
[12] MEISTERERNST M, ROGGE L, DONATH C, GANDER I, LOTTSPEICH $\mathrm{F}$ et al. Isolation and characterization of the porcine nuclear factor I (NFI) gene. FEBS Lett 1988; 236: 27-32. http://dx.doi.org/10.1016/0014-5793(88)80279-5

[13] RUPP RA, KRUSE U, MULTHAUP G, GOBEL U, BEYREUTHER K et al. Chicken NFI/TGGCA proteins are encoded by at least three independent genes: NFI-A, NFI-B and NFI-C with homologues in mammalian genomes. Nucleic Acids Res 1990; 18: 2607-16. http://dx.doi.org/10.1093/nar/18.9.2607

[14] FLETCHER CF, JENKINS NA, COPELAND NG, CHAUDHRY AZ, GRONOSTAJSKI RM. Exon structure of the nuclear factor I DNA-binding domain from C. elegans to mammals. Mamm Genome 1999; 10: 390-6. http://dx.doi. org/10.1007/s003359901008

[15] ALTMANN H, WENDLER W, WINNACKER EL. Transcriptional activation by CTF proteins is mediated by a bipartite low proline domain. Proc Natl Acad Sci USA 1994; 91: 3901-5. http://dx.doi.org/10.1073/pnas.91.9.3901

[16] MUKHOPADHYAY SS, WYSZOMIERSKI SL, GRONOSTAJSKI RM, ROSEN JM. Differential interactions of specific nuclear factor I isoforms with the glucocorticoid receptor and STAT 5 in the cooperative regulation of WAP gene transcription. Mol Cell Biol 2001; 21: 6859-69. http://dx.doi. org/10.1128/MCB.21.20.6859-6869.2001

[17] SINGH SK, WILCZYNSKA KM, GRZYBOWSKI A, YESTER J, OSRAH B et al. The unique transcriptional activation domain of nuclear factor-I-X3 is critical to specifically induce marker gene expression in astrocytes. J Biol Chem 2011; 286: 7315-7326. http://dx.doi.org/10.1074/jbc.M110.152421

[18.] LI G, MARGUERON R, HU G, STOKES D, WANG YH et al. Highly compacted chromatin formed in vitro reflects the dynamics of transcription activation in vivo. Mol Cell 2010; 38: 41-53. http://dx.doi.org/10.1016/j.molcel.2010.01.042

[19] STEFANCSIK R, SARKAR S. Relationship between the DNA binding domains of SMAD and NFI/CTF transcription factors defines a new superfamily of genes. DNA Seq 2003; 14: 233-9. http://dx.doi.org/10.1080/1085566031000141126

[20] BANDYOPADHYAY S, GRONOSTAJSKI RM. Identification of a conserved oxidation-sensitive cysteine residue in the NFI family of DNA-binding proteins. J Biol Chem 1994; 269: 29949-55.

[21] CHAUDHRY AZ, LYONS GE, GRONOSTAJSKI RM. Expression patterns of the four nuclear factor I genes during mouse embryogenesis indicate a potential role in development. Dev Dyn 1997; 208: 313-25. http://dx.doi.org/10.1002/(SICI)10970177(199703)208:3<313::AID-AJA3>3.0.CO;2-L

[22] DAS NEVES L, DUCHALA CS, TOLENTINO-SILVA F, HAXHIU MA, COLMENARES $C$ et al. Disruption of the murine nuclear factor I-A gene (Nfia) results in perinatal lethality, hydrocephalus, and agenesis of the corpus callosum. Proc Natl Acad Sci U S A 1999; 96: 11946-51. http://dx.doi. org/10.1073/pnas.96.21.11946

[23] STEELE-PERKINS G, Plachez C, BUTZ KG, YANG G, BACHURSKI CJ et al. The transcription factor gene Nfib is essential for both lung maturation and brain development. Mol Cell Biol 2005; 25: 685-98. http://dx.doi.org/10.1128/ MCB.25.2.685-698.2005 
[24] STEELE-PERKINS G, BUTZ KG, LYONS GE, ZEICHNERDAVID M, KIM HJ et al. Essential role for NFI-C/CTF transcription-replication factor in tooth root development. Mol Cell Biol 2003; 23: 1075-84. http://dx.doi.org/10.1128/ MCB.23.3.1075-1084.2003

[25] DRILLER K, PAGENSTECHER A, UHL M, OMRAN H, BERLIS A et al. Nuclear factor I X deficiency causes brain malformation and severe skeletal defects. Mol Cell Biol 2007; 27: 3855-67. http://dx.doi.org/10.1128/MCB.02293-06

[26] GRONOSTAJSKI RM. Roles of the NFI/CTF gene family in transcription and development. Gene 2000; 249: 31-45. http://dx.doi.org/10.1016/S0378-1119(00)00140-2

[27] HENG YH, BARRY G, RICHARDS LJ, PIPER M. Nuclear factor I genes regulate neuronal migration. Neurosignals 2012; 20: 159-67. http://dx.doi.org/10.1159/000330651

[28] NILSSON J, HELOU K, KOVACS A, BENDAHL PO, BJURSELL G et al. Nuclear Janus-activated kinase 2/nuclear factor 1-C2 suppresses tumorigenesis and epithelial-to-mesenchymal transition by repressing Forkhead box F1. Cancer Res 2010; 70: 2020-9. http://dx.doi.org/10.1158/0008-5472. CAN-09-1677

[29] MOREL Y, BAROUKI R. Down-regulation of cytochrome P450 1A1 gene promoter by oxidative stress. Critical contribution of nuclear factor 1. J Biol Chem 1998; 273: 26969-76. http://dx.doi.org/10.1074/jbc.273.41.26969

[30] NARVAEZ MJ, ANDERSON GR, PICKWELL GV, QUATTROCHI LC. Characterization of adjacent E-box and nuclear factor 1-like DNA binding sequence in the human CYP1A2 promoter. J Biochem Mol Toxicol 2005; 19: 78-86. http:// dx.doi.org/10.1002/ibt.20063

[31] LING G, HAUER CR, GRONOSTAJSKI RM, PENTECOST BT, DING X. Transcriptional regulation of rat CYP2A3 by nuclear factor 1: identification of a novel NFI-A isoform, and evidence for tissue-selective interaction of NFI with the CYP2A3 promoter in vivo. J Biol Chem 2004; 279: 27888-95. http://dx.doi.org/10.1074/jbc.M403705200

[32] LUCIAKOVA K, BARATH P, POLIAKOVA D, PERSSON A, NELSON BD. Repression of the human adenine nucleotide translocase-2 gene in growth-arrested human diploid cells: the role of nuclear factor-1. J Biol Chem 2003; 278: 30624-33. http://dx.doi.org/10.1074/jbc.M303530200

[33] EECKHOUTE J, CARROLL JS, GEISTLINGER TR, TORRES-ARZAYUS MI, BROWN M. A cell-type-specific transcriptional network required for estrogen regulation of cyclin D1 and cell cycle progression in breast cancer. Genes Dev 2006; 20: 2513-26. http://dx.doi.org/10.1101/gad.1446006

[34] NAKAMURA M, OKURA T, KITAMI Y, HIWADA K. Nuclear factor 1 is a negative regulator of gadd153 gene expression in vascular smooth muscle cells. Hypertension 2001; 37: 419-24. http://dx.doi.org/10.1161/01.HYP.37.2.419

[35] FURLONG EE, REIN T, MARTIN F. YY1 and NF1 both activate the human $\mathrm{p} 53$ promoter by alternatively binding to a composite element, and YY1 and E1A cooperate to amplify p53 promoter activity. Mol Cell Biol 1996; 16: 5933-45.

[36] OUELLET S, VIGNEAULT F, LESSARD M, LECLERC S, DROUIN R et al. Transcriptional regulation of the cyclin-dependent kinase inhibitor 1A (p21) gene by NFI in proliferating human cells. Nucleic Acids Res 2006; 34: 6472-87. http:// dx.doi.org/10.1093/nar/gkl861

[37] GAUSSIN A, MODLICH U, BAUCHE C, NIEDERLANDER NJ, SCHAMBACH A et al. CTF/NF1 transcription factors act as potent genetic insulators for integrating gene transfer vectors. Gene Ther 2012; 19: 15-24. http://dx.doi.org/10.1038/ gt.2011.70

[38] COOKE DW, LANE MD. The transcription factor nuclear factor I mediates repression of the GLUT4 promoter by insulin. J Biol Chem 1999; 274: 12917-24. http://dx.doi.org/10.1074/ jbc.274.18.12917

[39] BISGROVE DA, MONCKTON EA, PACKER M, GODBOUT R. Regulation of brain fatty acid-binding protein expression by differential phosphorylation of nuclear factor I in malignant glioma cell lines. J Biol Chem 2000; 275: 30668-76. http:// dx.doi.org/10.1074/jbc.M003828200

[40] BRUN M, COLES JE, MONCKTON EA, GLUBRECHT DD, BISGROVE D, GODBOUT R. Nuclear factor I regulates brain fatty acid-binding protein and glial fibrillary acidic protein gene expression in malignant glioma cell lines. J Mol Biol 2009; 391: 282-300. http://dx.doi.org/10.1016/j.jmb.2009.06.041

[41] MATSUOKA S, BALLIF BA, SMOGORZEWSKA A, McDONALD ER, III, HUROV KE et al. ATM and ATR substrate analysis reveals extensive protein networks responsive to DNA damage. Science 2007; 316: 1160-6. http://dx.doi.org/10.1126/ science. 1140321

[42] MUKHOPADHYAY SS, ROSEN JM. The C-terminal domain of the nuclear factor I-B2 isoform is glycosylated and transactivates the WAP gene in the JEG-3 cells. Biochem Biophys Res Commun 2007; 358: 770-6. http://dx.doi.org/10.1016/ j.bbrc.2007.04.185

[43] KANE R, MURTAGH J, FINLAY D, MARTI A, JAGGI R et al. Transcription factor NFIC undergoes N-glycosylation during early mammary gland involution. J Biol Chem 2002; 277: 25893-903. http://dx.doi.org/10.1074/jbc.M202469200

[44] DUVAL C, GAUDREAULT M, VIGNEAULT F, TOUZELDESCHENES L, ROCHETTE PJ et al. Rescue of the transcription factors Spl and NFI in human skin keratinocytes through a feeder-layer-dependent suppression of the proteasome activity. J Mol Biol 2012; 418: 281-99. http://dx.doi. org/10.1016/j.jmb.2012.01.021

[45] YANG SH, GALANIS A, WITTY J, SHARROCKS AD. An extended consensus motif enhances the specificity of substrate modification by SUMO. EMBO J 2006; 25: 5083-93. http:// dx.doi.org/10.1038/sj.emboj.7601383

[46] ROSSI P, KARSENTY G, ROBERTS AB, ROCHE NS, SPORN MB et al. A nuclear factor 1 binding site mediates the transcriptional activation of a type I collagen promoter by transforming growth factor-beta. Cell 1988; 52: 405-14. http://dx.doi.org/10.1016/S0092-8674(88)80033-3

[47] OHSHIMA T, SHIMOTOHNO K. Transforming growth factor-beta-mediated signaling via the p38 MAP kinase pathway activates Smad-dependent transcription through SUMO-1 modification of Smad4. J Biol Chem 2003; 278: 50833-42. http://dx.doi.org/10.1074/jbc.M307533200

[48] YU L, HEBERT MC, ZHANG YE. TGF-beta receptoractivated p38 MAP kinase mediates Smad-independent 
TGF-beta responses. EMBO J 2002; 21: 3749-59. http://dx.doi. org/10.1093/emboj/cdf366

[49] LUCIAKOVA K, KOLLAROVIC G, BARATH P, NELSON BD. Growth-dependent repression of human adenine nucleotide translocator-2 (ANT2) transcription: evidence for the participation of Smad and Sp family proteins in the NF1-dependent repressor complex. Biochem J 2008; 412: 123-30. http://dx.doi. org/10.1042/BJ20071440

[50] LUCIAKOVA K, KOLLAROVIC G, KRETOVA M, SABOVA L, NELSON BD. TGF-beta signals the formation of a unique NF1/Smad4-dependent transcription repressorcomplex in human diploid fibroblasts. Biochem Biophys Res Commun 2011; 411: 648-53. http://dx.doi.org/10.1016/ j.bbrc.2011.07.017

[51] PLASARI G, CALABRESE A, DUSSERRE Y, GRONOSTAJSKI RM, McNAIR A et al. Nuclear factor I-C links platelet-derived growth factor and transforming growth factor betal signaling to skin wound healing progression. Mol Cell Biol 2009; 29: 6006-17. http://dx.doi.org/10.1128/MCB.01921-08

[52] PLASARI G, EDELMANN S, HOGGER F, DUSSERRE Y, MERMOD N et al. Nuclear factor I-C regulates TGF-\{beta\}dependent hair follicle cycling. J Biol Chem 2010; 285: 34115-25. http://dx.doi.org/10.1074/jbc.M110.120659

[53] LEE DS, YOON WJ, CHO ES, KIM HJ, GRONOSTAJSKI $\mathrm{RM}$ et al. Crosstalk between nuclear factor I-C and transforming growth factor-betal signaling regulates odontoblast differentiation and homeostasis. PLoS One 2011; 6: e29160. http://dx.doi.org/10.1371/journal.pone.0029160

[54] NILSSON J, BJURSELL G, KANNIUS-JANSON M. Nuclear Jak2 and transcription factor NF1-C2: a novel mechanism of prolactin signaling in mammary epithelial cells. Mol Cell Biol 2006; 26: 5663-74. http://dx.doi.org/10.1128/MCB.02095-05

[55] UDELHOVEN M, LEESER U, FREUDE S, HETTICH MM, LAUDES $M$ et al. Identification of a region in the human IRS2 promoter essential for stress induced transcription depending on SP1, NFI binding and ERK activation in HepG2 cells. J Mol Endocrinol 2010; 44: 99-113. http://dx.doi.org/10.1677/JME08-0182

[56] URAMOTO H, IZUMI H, NAGATANI G, OHMORI H, NAGASUE N et al. Physical interaction of tumour suppressor p53/p73 with CCAAT-binding transcription factor 2 (CTF2) and differential regulation of human high-mobility group 1 (HMG1) gene expression. Biochem J 2003; 371: 301-10. http://dx.doi.org/10.1042/BJ20021646

[57] NAYAK BK, DAS BR. Differential binding of nuclear proteins to the TP53 gene promoter in male breast tumour. Eur J Cancer 1997; 33: 1484-7. http://dx.doi.org/10.1016/S0959$\underline{\text { 8049(97)00164-0 }}$

[58] SUN P, DONG P, DAI K, HANNON GJ, BEACH D. p53independent role of MDM2 in TGF-betal resistance. Science 1998; 282: 2270-2. http://dx.doi.org/10.1126/ science.282.5397.2270

[59] JOHANSSON FK, BRODD J, EKLOF C, FERLETTA M, HESSELAGER $\mathrm{G}$ et al. Identification of candidate cancercausing genes in mouse brain tumors by retroviral tagging.
Proc Natl Acad Sci U S A 2004; 101: 11334-7. http://dx.doi. org/10.1073/pnas.0402716101

[60] SCRIDELI CA, CARLOTTI CG, JR., OKAMOTO OK, ANDRADE VS, CORTEZ MA et al. Gene expression profile analysis of primary glioblastomas and non-neoplastic brain tissue: identification of potential target genes by oligonucleotide microarray and real-time quantitative PCR. J Neurooncol 2008; 88: 281-91. http://dx.doi.org/10.1007/ $\underline{\text { s11060-008-9579-4 }}$

[61] SONG HR, GONZALES-GOMEZ I, SUH GS, COMMINS DL, SPOSTO R et al. Nuclear factor IA is expressed in astrocytomas and is associated with improved survival. Neuro Oncol 2010; 12: 122-32. http://dx.doi.org/10.1093/neuonc/nop044

[62] MALIN D, KIM IM, BOETTICHER E, KALIN TV, RAMAKRISHNA $S$ et al. Forkhead box F1 is essential for migration of mesenchymal cells and directly induces integrin-beta3 expression. Mol Cell Biol 2007; 27: 2486-98. http://dx.doi. org/10.1128/MCB.01736-06

[63] TOBIOKA H, ISOMURA H, KOKAI Y, TOKUNAGA Y, YAMAGUCHI J et al. Occludin expression decreases with the progression of human endometrial carcinoma. Hum Pathol 2004; 35: 159-64. http://dx.doi.org/10.1016/ j.humpath.2003.09.013

[64] HAN W, JUNG EM, CHO J, LEE JW, HWANG KT et al. DNA copy number alterations and expression of relevant genes in triple-negative breast cancer. Genes Chromosomes Cancer 2008; 47: 490-9. http://dx.doi.org/10.1002/gcc.20550

[65] MOON HG, HWANG KT, KIM JA, KIM HS, LEE MJ et al. NFIB is a potential target for estrogen receptor-negative breast cancers. Mol Oncol 2011; 5: 538-44. http://dx.doi. org/10.1016/j.molonc.2011.08.002

[66] LANDREVILLE S, VIGNEAULT F, BERGERON MA, LECLERC S, GAUDREAULT $M$ et al. Suppression of alpha5 gene expression is closely related to the tumorigenic properties of uveal melanoma cell lines. Pigment Cell Melanoma Res 2011; 24: 643-55. http://dx.doi.org/10.1111/ j.1755-148X.2011.00869.x

[67] RATHINAM R, ALAHARI SK. Important role of integrins in the cancer biology. Cancer Metastasis Rev 2010; 29: 223-37. http://dx.doi.org/10.1007/s10555-010-9211-x

[68] ZHOU Z, FLESKEN-NIKITIN A, CORNEY DC, WANG W, GOODRICH DW et al. Synergy of p53 and Rb deficiency in a conditional mouse model for metastatic prostate cancer. Cancer Res 2006; 66: 7889-98. http://dx.doi.org/10.1158/ 0008-5472.CAN-06-0486

[69] DOOLEY AL, WINSLOW MM, CHIANG DY, BANERJI S, STRANSKY $\mathrm{N}$ et al. Nuclear factor $\mathrm{I} / \mathrm{B}$ is an oncogene in small cell lung cancer. Genes Dev 2011; 25: 1470-5. http://dx.doi. org/10.1101/gad.2046711

[70] WISTUBA II, GAZDAR AF, MINNA JD. Molecular genetics of small cell lung carcinoma. Semin Oncol 2001; 28: 3-13. http://dx.doi.org/10.1016/S0093-7754(01)90072-7

[71] SCHUUR ER, KRUSE U, IACOVONI JS, VOGT PK. Nuclear factor I interferes with transformation induced by nuclear oncogenes. Cell Growth Differ 1995; 6: 219-27. 